\title{
MGP T-138C Polymorphism (TT Genotype) is Associated with Vascular Calcification Incidence in Indonesian Regular Hemodialysis Patients
}

\author{
Muhammad Hanif Wibowo ${ }^{1}$, Riri Andri Muzasti ${ }^{1,2, *}$, Syafrizal Nasution ${ }^{1,2}$ \\ ${ }^{1}$ Department of Internal Medicine, Faculty of Medicine, Universitas Sumatera Utara/ Haji Adam Malik General Hospital, \\ J1. Dr. Mansyur No.5, Medan, Indonesia \\ ${ }^{2}$ Division of Nephrology and Hypertension, Department of Internal Medecine, Faculty of Medicine, Universitas Sumatera Utara/ \\ Haji Adam Malik General Hospital, Jl. Dr. Mansyur No.5, Medan, Indonesia \\ *Corresponding author. E-mail: riri.andri@usu.ac.id
}

Received date: Feb 5, 2020; Revised date: Aug 30, 2020; Accepted date: Sep 1, 2020

\section{Abstract}

B ACKGROUND: Vascular calcification contributes greatly to the incidence of cardiovascular disease. Previously, vascular calcification was considered as a passive process caused by the mineral deposition from the circulation. Nowadays, researchers have found inhibitors and promoter factors from vascular calcification, one of which is the matrix gla protein (MGP). MGP levels depend on the gene that encodes them. The MGP T-138C polymorphism is one of the most common causes of vascular calcification.

METHODS: This was a case-control study involving 86 chronic kidney disease (CKD) patients who underwent regular hemodialysis in Rasyida Kidney Hospital, Medan, Indonesia. Vascular calcification was determined from

\section{Introduction}

Vascular calcification contributes significantly to the incidence and the average mortality of the cardiovascular disease.(1) Based on the Indonesian Renal Registry in 2017, the highest mortality rate in hemodialysis (HD) patients is due to cardiovascular disease.(2) Vascular calcification was previously regarded as a passive process caused by circulatory deposition of minerals, mainly in patients with mineral imbalances. Currently, there are both inhibitory and promoting factors found from vascular calcification, 1 one of which is the Matrix Gla Protein (MGP).(3-5) This protein is a vitamin $\mathrm{K}$-dependent protein that gives a direct effect to lateral and posteroanterior abdominal X-ray. The MGP T-138 C polymorphism was analyzed using polymerase chain reaction restriction fragment length polymorphism (PCR-RFLP).

RESULTS: The TT/TC genotype associates with the incidence of vascular calcification with OR of $3.52,95 \%$ CI: 1.23-10.106 ( $p$-value $<0.001)$.

CONCLUSION: There is an association between MGP $\mathrm{T}-138 \mathrm{C}$ polymorphism, particularly on $\mathrm{T}$ Allele with the incidence of vascular calcification in CKD patients undergoing regular hemodialysis.

KEYWORDS: hemodialysis, T-138 C polymorphism, vascular calcification, matrix GLA protein

Indones Biomed J. 2020; 12(4): 320-4 blood vessels by inhibiting the formation of calcium crystal together with other calcification inhibitors such as fetuin-A. MGP also binds to bone morphogenetic protein-2 (BMP-2), a growth factor that converts vascular smooth muscle cells into osteoblast-like cells, and also binds with extracellular matrix components and act as an anti-apoptosis.(5-7) MGP is the first recognized protein to act as an in vivo calcification inhibitor. MGP is produced by bone and smooth muscle.(8) Several studies have identified polymorphisms in the MGP gene, and they are associated with various phenotypes. $(9,10)$ Recent research has focused on the T-138 C polymorphism found in the promoter region.

The concentration of MGP levels depends on the genes that encode them.(8) The MGP T-138C polymorphism (rs 
1800802) lies in the promoter region.(9) Based on previous studies it was found that the TT genotypes have 30\% lower MGP serum levels in contrast to the CC genotypes, thus the TT genotypes accelerated the vascular calcification more prominently.(9) Conversely, another study concluded that the CC genotype of the MGP T-138C polymorphism was associated with slower progression of vascular calcification found in patients undergoing HD regularly.(10) This study set out to investigate the association of the MGP T-138C polymorphism with the incidence of vascular calcification in regular HD patients in Indonesia.

\section{Methods}

This case-control study received ethical approval from the Health Research Ethical Committee, Faculty of Medicine, Universitas Sumatera Utara (No. 313/TGL/KEPK FK USU-RSUP HAM/2019). Patients who were undergoing regular HD at Haji Adam Malik Hospital, Medan, Indonesia between May to July 2019, were enrolled in this study as subjects. The inclusion criteria were chronic kidney disease (CKD) subjects who had undergone HD for more than 26 months and were 22-79 years old. Subjects with incomplete data were excluded from the study.

Eighty-six subjects were selected by the consecutive sampling method. The subjects were then divided into two groups; subjects with vascular calcification and without vascular calcification based on the results of the lateral and posteroanterior abdominal X-ray. Data of age, sex, duration of HD were obtained from medical records.

\section{MGP T-138C Polymorphism Test}

Blood samples from both groups were collected to obtain the genomic deoxyribonucleic acid (DNA) structure. The DNA extraction was examined by polymerase chain reaction (PCR) technique. The PCR restriction fragment length polymorphism (PCR-RFLP) was used for the analysis of the MGP T-138C Polymorphism in the Integrated Laboratory in the Faculty of Medicine, Universitas Sumatera Utara. The PCR technique was done using Veriti 96 Well Thermal Cylinder (Thermo Fisher Scientific, Waltham, MA, USA). The genotyping process was conducted based on previous study method with a slight modification.(9) Genomic DNA was amplified in the following primary sequence: 5 'AAG CAT ACG ATG GCC AAA ACT TCT GCA 3 ' (forward) and 5'GAA CTA GCA TTG GAA CTT TTC CCA ACC $3^{\prime}$ (reverse). The parameters of the amplification were as follows: firstly, denaturation was done for 5 minutes at $94^{\circ} \mathrm{C}$. Thirty-six cycles for 1 minute at $94^{\circ} \mathrm{C}, 1$ minute at $59^{\circ} \mathrm{C}, 1$ minute at $72^{\circ} \mathrm{C}$ and 10 minutes for the final extension at $72^{\circ} \mathrm{C}$. The PCR product (142 base pair-bp) was digested using the $5 \mathrm{U}$ restriction enzyme of Bsrl (New England Biolabs, Ipswich, MA, USA) at $65^{\circ} \mathrm{C}$ for 30 minutes and followed by thermal inactivation at $80^{\circ} \mathrm{C}$ for 20 minutes. The retention pattern for $-138 \mathrm{C}$ alleles contains $142 \mathrm{bp}$ fragments. Polymorphism of $-138 \mathrm{~T}$ was made into a frictional position and was digested into 118-24 bp fragment. The restriction product was then divided into $2.5 \%$ agarose gel and visualized by etching ethidium bromide.

\section{Data Analysis}

Univariate data analysis was conducted to determine the frequency distribution. Categorical variables were presented as frequencies (n) and percentages (\%), while numerical variables were presented as mean and standard deviation for normally distributed data and as categorical variables for not normally distributed data. A $p$-value $<0.05$ was considered statistically significant. Data analysis was done by using SPSS Ver. 24 (IBM Coorporation, Armonk, NY, USA).

\section{Results}

Eighty-six subjects who met the inclusion criteria were included, 42 subjects were male (48.8\%), and 44 subjects of them were female (51.2\%). The median age was 59 years (32-79 years). The majority of all 86 subjects were Bataknese (65.1\%), followed by 17 Malays (19.8\%), 3 Chinese (3.5\%), and 10 Javanese $(11.6 \%)$. The median duration of HD was 45 months (27-229 months). The majority of subjects had hypertension as the comorbid disease in 60 people $(69.8 \%)$, followed by diabetes mellitus in 18 people $(20.9 \%)$.

From the results of RFLP examination on the MGP T-138C polymorphism, the majority of subjects had TT genotype found in 40 subjects $(46.5 \%)$, followed by TC genotype in 28 subjects (32.6\%) and CC subjects in 18 people $(20.9 \%)$ (Table 1$)$.

As gender matching was arranged, the same number of female and male was obtained, which was 21 male patients $(50.0 \%)$ in the case group and 22 female patients $(50.0 \%)$ in the control group (Table 2). Mean age was $54.40 \pm 1.5$ years and $58.67 \pm 1.661$ years in the case and the control group, respectively. In the case group, the average HD duration was 45 months and 46 months in the control group.

The first set of analysis was to determined whether there was any significant differences between the characteristics 
Table 1. Subject's characteristics.

\begin{tabular}{lc}
\hline \multicolumn{1}{c}{ Characteristics } & $\mathbf{n}=\mathbf{8 6}(\mathbf{1 0 0} \%)$ \\
\hline Sex, $\mathrm{n}(\%)$ & $42(48.8 \%)$ \\
Male & $44(51.2 \%)$ \\
Female & $59(32-79)$ \\
\hline Age (years), Median (Min-Max) & \\
\hline Ethnic Group, n (\%) & $56(65.1 \%)$ \\
Bataknese & $17(19.8 \%)$ \\
Malay & $3(3.5 \%)$ \\
Tionghoa & $10(11.6 \%)$ \\
Javanese & $45(27-229)$ \\
\hline HD Duration (months), Median (Min-Max) & \\
\hline Hypertension (\%) & $60(69.8 \%)$ \\
Yes & $26(30.2 \%)$ \\
No & $18(20.9 \%)$ \\
\hline Diabetes Mellitus, $\mathrm{n}(\%)$ & $68(79.1 \%)$ \\
Yes & \\
No & $40(46.5 \%)$ \\
\hline T-138 C Polymorphism, n (\%) & $28(32.6 \%)$ \\
TT & $18(20.9 \%)$ \\
TC & \\
CC &
\end{tabular}

of the study population of those with vascular calcification in the case group and those without in the control group. Based on the characteristics of the study population shown in Table 2, there was no evidence that each of the characteristic variables had any significant differences. The characteristics included age, HD duration, ethnic group and comorbid disease such as hypertension and diabetes mellitus. None of these variables was statistically proven with $p$-value $\geq 0.05$.

The next section of the survey was concerned with the association between the MGP T-138 C polymorphism of TT, CC and CC genotypes with the incidence of vascular calcification. Stepwise multiple regression analysis was performed to investigate the significance of possible predictors of vascular calcification as assessed by correlation analysis. The results, as shown in Table 3, indicated that there was an insignificant association between the TT, TC and CC genotypes with the incidence of vascular calcification with $p$-value $=0.06$. Another set of groups tested for association was by grouping the subjects into two different set of genotypes which was TT genotype versus TC/CC genotype and TT/TC genotype versus CC genotype. No significant association found in first grouping with $p$-value $=0.195$ while the next group showed a significant association between the TT/TC genotypes versus CC genotype with the incidence of vascular calcification with $p$-value $=0.001$ (PR: 7.14 with 95\% CI: 1.88-27.01) (Table 3).

\section{Discussion}

The majority of the subjects consisted of female $(51.2 \%)$ with a median age of 59 years. The age characteristics of

Table 2. Characteristics and comparison between case and control group.

\begin{tabular}{|c|c|c|c|}
\hline \multirow[b]{2}{*}{ Characteristics } & Case $(n=43)$ & Control ( $n=43)$ & \multirow[b]{2}{*}{$p$-value* } \\
\hline & $\begin{array}{c}\text { (Vascular } \\
\text { Calcification) }\end{array}$ & $\begin{array}{l}\text { (No Vascular } \\
\text { Calcification) }\end{array}$ & \\
\hline \multicolumn{4}{|l|}{ Gender, n (\%) } \\
\hline Male & $21(48.8 \%)$ & $21(48.8 \%)$ & - \\
\hline Female & $22(51.1 \%)$ & $22(51.1 \%)$ & \\
\hline Age (Years), Mean \pm S.D & $54.40 \pm 10.19$ & $58.67 \pm 10.89$ & 0.95 \\
\hline HD Duration (Months), Median (Min-Max) & $45(27-142)$ & $46(28-229)$ & 0.713 \\
\hline \multicolumn{4}{|l|}{ Ethnic Group, n (\%) } \\
\hline Bataknese & $31(72.1 \%)$ & $25(58.1 \%)$ & 0.059 \\
\hline Malay & $9(20.9 \%)$ & $8(18.6 \%)$ & \\
\hline Chinese & $1(2.3 \%)$ & $9(20.9 \%)$ & \\
\hline Javanese & $2(4.7 \%)$ & $1(2.3 \%)$ & \\
\hline \multicolumn{4}{|l|}{ Hypertension, $\mathrm{n}(\%)$} \\
\hline Yes & $30(69.8 \%)$ & $30(69.8 \%)$ & 1 \\
\hline No & $13(30.2 \%)$ & $13(30.2 \%)$ & \\
\hline \multicolumn{4}{|l|}{ Diabetes Mellitus, n (\%) } \\
\hline Yes & $10(23.3 \%)$ & $8(18.6 \%)$ & 0.596 \\
\hline No & $33(76.7 \%)$ & $35(81.4 \%)$ & \\
\hline
\end{tabular}

*T-test analysis used for comparison between the two numerical variables that was normally distributed; Mann-Whitney U test for data not normally distributed; Chi-square test for comparison between categorical data type and Fisher's exact test if the Chi Square did not met the requirement. 
Table 3. Association between MGP T-138 C polymorphism with vascular calcification.

\begin{tabular}{|c|c|c|c|c|c|}
\hline Chorettrictis & Case $(n=43)$ & Control $(n=43)$ & & & \\
\hline (MGP T-138C Genotypes) & $\begin{array}{c}\text { (Vascular } \\
\text { Calcification) }\end{array}$ & $\begin{array}{c}\text { (Non Vascular } \\
\text { Calcification) }\end{array}$ & $p$-value* & OR & $95 \%$ CI \\
\hline $\mathrm{TT}$ & $23(57.5 \%)$ & $17(42.5 \%)$ & \multirow{3}{*}{0.06} & \multirow{3}{*}{-} & \multirow{3}{*}{-} \\
\hline $\mathrm{TC}$ & $17(60.7 \%)$ & $11(39.3 \%)$ & & & \\
\hline $\mathrm{CC}$ & $3(16.7 \%)$ & $15(83.3 \%)$ & & & \\
\hline $\mathrm{TT} / \mathrm{TC}$ & $40(58.8 \%)$ & $28(41.2 \%)$ & \multirow{2}{*}{0.001} & \multirow{2}{*}{3.52} & \multirow{2}{*}{$1.23-10.106$} \\
\hline $\mathrm{CC}$ & $3(16.7 \%)$ & $15(83.3 \%)$ & & & \\
\hline TT & $23(57.5 \%)$ & $17(42.5 \%)$ & \multirow{2}{*}{0.195} & \multirow{2}{*}{1.759} & \multirow{2}{*}{$0.747-4.140$} \\
\hline $\mathrm{TC} / \mathrm{CC}$ & $20(43.5 \%)$ & $26(56.5 \%)$ & & & \\
\hline
\end{tabular}

* $p$-values of $\chi^{2}$ test for differences in frequencies of MGP T-138C genotypes in case and control groups.

this study is consistent with previous study, where the mean age of patients suffering from kidney failure with GFR of $<60 \mathrm{~mL} / \mathrm{min} / 1.73 \mathrm{~m}^{2}$ was $63.6 \pm 14.7 .11$. This study is also in line with the reports from Indonesian Renal Registry (IRR) in 2017, where the largest proportion of patients undergoing $\mathrm{HD}$ is in the age range of 45-64 years.(2)

In this study, the most common comorbid disease was hypertension, followed by diabetes mellitus. The high number of hypertension comorbid in Indonesia was most likely due to the late referral of patients that induce secondary hypertension arousal caused by kidney failure itself.

The HD duration showed no significant difference between group with vascular calcification and group without it. This was inversely proportional to the report of the Calcification of Outcome in Renal Disease (CORD Study). This inconsistency of study results may be due to the fact that the duration of HD in both groups of this study was similar and thus limit the analysis in proving the association between the duration of $\mathrm{HD}$ with the occurrence of calcification.

From the results of PCR-RFLP of the T-138C gene, the significant association between TT genotypes and vascular calcification incidence reflects that there was a higher probability of TT genotypes to accelerate calcification in vascular. Although this was not the case analyzed statistically in the study, this result calls for an extend into another cohort study. One study stated that TT genotype was associated with increased carotid IntimaMedia Thickness (cIMT), a vascular calsification marker. (9) This finding would add insight that inflammation and vascular calcification are interrelated and encourage for further study.
Another findings also suggested that CC Genotype caused slower progression of vascular calcification compared to the the TT/TC.10 The CC genotype was thought to increase local activation of MGP itself regardless of MGP levels in serum and had the potential to inhibit vascular calcification in CKD patients undergoing regular HD.(10) The occurrence of vascular calcification in the TT genotype might be due to the T allele of the MGP gene expression itself and also due to the high frequency of the TT genotype that were found more in CKD patients with regular HD.(9) This, in turn, caused a less amount of MGP circulating in the plasma and accelerating more vascular calcification.

In contrast to the previous explanation, another study on $\mathrm{T}-138 \mathrm{C}$ was found to affect transcription activity in the MGP gene. $C$ allele as the promoter of serum MGP was four times higher than the $\mathrm{T}$ variant. This was due to the binding of the T allele to the AP-1 complex and induced by phorbol 12-myristate 13-acetate, while the $\mathrm{C}$ allele was resistance to the substance. Hence, the $\mathrm{C}$ allele provided protection against tissue calcification in VSMC with the MGP gene transcription mechanism, whereas the $\mathrm{T}$ allele gave results via AP-1 that were more directed towards the occurrence of calcification.(20) Further large-scale studies with extent characteristics are required to confirm the significance found between the gene polymorphism and occurrence of vascular calcification in CKD patients.

\section{Conclusion}

It can be concluded that there was a significant association between MGP T-138 C gene polymorphism, particularly on $\mathrm{T}$ Allele with the incidence of vascular calcification in CKD patients undergoing regular HD. 


\section{References}

1. Schoppet M, Shroff RC, Hofbauer LC, Shanahan CM. Exploring the biology of vascular calcification in chronic kidney disease: what is circulating? Kidney Int. 2008; 73: 384-90.

2. Society of Nephrology Indonesia (Perhimpunan Nefrologi Indonesia/ PERNEFRI). 10th Report of Indonesian Renal Registry. Jakarta: PERNEFRI; 2017.

3. Luo G, Ducy P, McKee MD, Pinero GJ, Loyer E, Behringer RR, et al. Spontaneous calcification of arteries and cartilage in mice lacking matrix GLA protein. Nature. 1997; 386: 78-81.

4. Munroe PB, Olgunturk RO, Fryns JP, Van Maldergem L, Ziereisen $\mathrm{F}$, Yuksel B, et al. Mutations in the gene encoding the human matrix Gla protein cause Keutel syndrome. Nat Genet. 1999; 21: 142-4.

5. Hallajzadeh J, Ghorbanihaghjo A, Argani H, Dastmalchi S, Rashtchizadeh N. Growth arrest-specific 6 protein and matrix Gla protein in hemodialysis patients. Iran J Kidney Dis. 2015; 9: 24955.

6. Silaghi CN, Crăciun AM, Cristea VJH, Medicine V. Matrix Gla protein: the inhibitor of vascular and osteoarticular calcifications. HVM Bioflux. 2011; 3: 178-90.

7. Wuyts J, Dhondt AJACB. The role of vitamin $\mathrm{K}$ in vascular calcification of patients with chronic kidney disease. Acta Clinica Belgica. 2016; 71: 462-7.

8. Kobayashi N, Kitazawa R, Maeda S, Schurgers LJ, Kitazawa S. T-138C polymorphism of matrix Gla protein promoter alters its expression but is not directly associated with atherosclerotic vascular calcification. 2004; 50: 69-81.

9. Roumeliotis S, Roumeliotis A, Panagoutsos S, Giannakopoulou E, Papanas N, Manolopoulos VG, et al. Matrix Gla protein T-138C polymorphism is associated with carotid intima-media thickness and predicts mortality in patients with diabetic nephropathy. J Diabetes Complications. 2017; 31: 1527-32.

10. Yoshikawa K, Abe H, Tominaga T, Nakamura M, Kishi S, Matsuura $\mathrm{M}$, et al. Polymorphism in the human matrix Gla protein gene is associated with the progression of vascular calcification in maintenance hemodialysis patients. Clin Exp Nephrol. 2013; 17: $882-9$
11. Zhang L, Wang F, Wang L, Wang W, Liu B, Liu J, et al. Prevalence of chronic kidney disease in China: a cross-sectional survey. Lancet. 2012; 379: 815-22.

12. Aucella F, Corsonello A, Leosco D, Brunori G, Gesualdo L, Antonelli-Incalzi R. Beyond chronic kidney disease: the diagnosis of Renal Disease in the Elderly as an unmet need. A position paper endorsed by the Italian Society of Nephrology (SIN) and Italian Society of Geriatrics and Gerontology (SIGG). J Nephrol. 2019; 32: 165-76.

13. Saran R, Li Y, Robinson B, Ayanian J, Balkrishnan R, Bragg-Gresham $\mathrm{J}$, et al. US renal data system 2014 annual data report: epidemiology of kidney disease in the United States. Am J Kidney Dis. 2015; 66 (1 Suppl 1): Svii, S1-305.

14. Muzasti RA, Loesnihari R. High fetuin-A level as a protective factor to abdominal aortic calcification in Indonesian regular hemodialysis patients.Open Access Maced J Med Sci.2019; 7: 721-5.

15. Kraus MA, Kalra PA, Hunter J, Menoyo J, Stankus N. The prevalence of vascular calcification in patients with end-stage renal disease on hemodialysis: a cross-sectional observational study. Ther Adv Chronic Dis. 2015; 6: 84-96.

16. Coll B, Betriu A, Martínez-Alonso M, Amoedo ML, Arcidiacono $\mathrm{MV}$, Borras M, et al. Large artery calcification on dialysis patients is located in the intima and related to atherosclerosis. Clin J Am Soc Nephrol. 2011; 6: 303-10.

17. Honkanen E, Kauppila L, Wikström B, Rensma PL, Krzesinski JM, Aasarod K, et al. Abdominal aortic calcification in dialysis patients: results of the CORD study. Nephrol Dial Transplant 2008; 23: 400915.

18. Price PA, Fraser JD, Metz-Virca G. Molecular cloning of matrix Gla protein: implications for substrate recognition by the vitamin K-dependent gamma-carboxylase. Proc Natl Acad Sci USA. 1987; 84: 8335-9.

19. Herrmann SM, Whatling C, Brand E, Nicaud V, Gariepy J, Simon $\mathrm{A}$, et al. Polymorphisms of the human matrix GLA protein (MGP) gene, vascular calcification, and myocardial infarction. Arterioscler Thromb Vasc Biol. 2000; 20: 2386-93.

20. Garbuzova VY, Gurianova VL, Stroy DA, Dosenko VE, Parkhomenko $\mathrm{AN}$, Ataman AV. Association of matrix Gla protein gene allelic polymorphisms $(\mathrm{G}-7 \rightarrow \mathrm{A}, \mathrm{T}-138 \rightarrow \mathrm{C}$, and $\mathrm{Thr} 83 \rightarrow$ Ala) with the acute coronary syndrome in the Ukrainian population.Clinical Cardiology. 2012; 17: 30-3. 